\title{
Typological thinking strikes again
}

\author{
Proudlove, G.S. 2006. Subterranean fishes of the world. International Society \\ for Subterranean Biology, Moulis. 287 pp. US\$ 65.
}

\author{
Aldemaro Romero
}

Received: 15 December 2006/ Accepted: 18 December 2006/Published online: 1 February 2007

(C) Springer Science+Business Media B.V. 2007

"Facts are stupid until brought into connection with some general law"

\section{Louis Agassiz}

At the time that the famous Swiss-American naturalist Louis Agassiz (1807-1873) wrote the above-referenced quote in mid-19th century, the common meaning of the word "stupid" was that of "Void of interest, tiresome, boring, dull." (Oxford English Dictionary). He, of course, never meant that facts were useless; after all, he used a lot of them. His point was that the main objective of science was to explain the facts. As Ernst Mayr reasoned, the why-questions are the most interesting questions of science (Mayr 1982, p. 7).

Blind cave animals in general and fishes in particular, have attracted the attention of researchers from around the world for several centuries. After all, these organisms epitomize the incongruity to the view of evolution as being a "progressive" or "constructive" phenomenon. Many cave species seem to have some of their characters structurally reduced or even absent, particularly eyes and pigmentation. The first

\footnotetext{
A. Romero $(\square)$

Department of Biological Sciences, Arkansas State University, P.O. Box 559, State University, AR 72467, USA

e-mail: aromero@astate.edu
}

serious studies were carried out by the leaders of the North American evolutionary movement (who were more neo-Lamarckian than Darwinian) in the second half of the nineteenth century. They were so obsessed with these creatures that they made the cave species of the North American fish family Amblyopsidae the poster organisms of their research programs. The first third of the 20th century was dominated by taxonomic studies with a strong typological thinking of automatically naming new blind cave fish populations as new genera and species just by the virtue of their lack of eyes and pigmentation. Then came the expansion of cave fish research to include aspects such as ecology, behavior and physiology led by the American ichthyologist Charles Breder (1897-1983). The last phase of these studies began in the 1970s and has concentrated on genetic and "evo-devo" reseasrch of these animals (Romero 2001).

So given the big amount of information that has been generated, any attempt of compiling known facts about blind cave fishes is welcome. With more than 100 species described from all continents except in Europe and Antarctica that compilation is a daunting task, especially given that most new species described are from China in papers published in Chinese and in journals whose access is many times not easy. Dr. Graham S. Proudlove (with whom I have coauthored a paper in the past) took on such task. 
Proudlove's book is basically divided into fours parts: Part 1: an introduction that includes a checklist of the subterranean fishes of the world up to 2003, a note on the "coexistence" of (sympatric) species, another on the conservation status of these fishes, a section on "non-troglobitic" (eyed, pigmented) subterranean fishes and "a brief history of investigations (1842-2003)". This last component is rather a chronological account of discoveries rather than a historical analysis. The title of this section is indeed a contradiction with the text itself, since the author mentions that the first publication that reports a blind cave fish dates back to 1541. Part 2: The species account which includes a number of "undescribed" species and "other possible stygobitic" (blind, depigmented) subterranean fishes. In this section the author tries to list museum specimens for those species. Unfortunately that list is quite incomplete and gives the impression that a disproportionate number of museum specimens of blind cave fishes are at the British Museum of Natural History, which is not the case. Part 3: A bibliography of these fishes up to 2004 (which is nearly exhaustive). Part 4: Appendices and a note added in proof.

The reader will find an incredible number of facts and factoids about these organisms, and it is certainly a valuable reference for those interested in knowing more on this topic. Most of the species mentioned in the text are accompanied by a linedrawing illustration, although the artistic representation is less than precise. At the end of the book there are some color plates with pictures of some of the species although some of them of not very high quality. Other figures are of low quality having been reproduced from poor computer printouts. For example, the map for the distribution of cave fish localities on page 47 is too crude and difficult to read for areas that have high concentration of localities (like China, for example) (compare with Romero and Paulson 2001).

All pages previous to the main text lack numbering despite the fact that references are made to them in the Index. But problems do not circumscribe to formatting but also to writing as well. There are some inscrutable passages. For example, on page 282 there is a section titled "The neutral mutation versus adaptation models for troglomorphy" where in a single paragraph the author wrote that "there has been a debate about relative contributions of neutral mutation and adaptation in the evolution of troglomorphy" (...) "there is now a possible answer" (...) "a first contribution from adaptation, followed by a pleiotropic contribution, leads to loss of eyes in this species". Obviously, these statements are vague to say the least.

As Proudlove recognizes in his Acknowledgements section (p. ix) the book is "not an original work but a compilation." The problem is that the author sometimes tries to convey some thinking of his own which is typological in nature. For example, he keeps calling blind and depigmented fishes "true hypogean (stygobotic) species" (p. 33) because they display reduction and/or loss of eyes and pigmentation. Yet, he lists a large number (more than 100) fish species found in caves that do not happen to be either blind or depigmented; he dismisses them as "accidentals" without considering their potential ecological and evolutionary importance. This lack of broader vision opens the door to questions such as: should we dismiss the role played by bats in the ecology of caves just because they are neither blind nor depigmented? Should not we be studying more carefully eyed, pigmented fishes in caves to answer critical questions about the evolution of cave organisms?

This typological thinking gets to an extreme when Proudlove renames cave populations as new species just for the sake of it. For example, the most studied blind cave fish species is the blind cave tetra from Mexico. The first blind cave population (from La Cueva Chica in the Sierra del Abra area) was named Anoptichthys jordani (Hubbs and Innes 1936), the second one (from La Cueva El Pachón) was named Anoptichthys antrobius (Alvarez 1946), and a third one (from La Cueva de Los Sabinos) was named Anoptichthys hubbsi (Alvarez 1947). As more cave populations were discovered it became evident that this typological approach was creating a lot of confusion by ballooning the number of species just based on populations found in nearby localities (Romero 2001). With the pioneering work by Wilkens (1971), Avise and Selander (1972), and others, it became clear that the eyed, pigmented 
(epigean or surface) populations and the blind, depigmented (hypogean or cave) populations were part of the same species. Since then virtually all authors have referred to both of these morphs or ecotypes as members of either Astyanax fasciatus or Astyanax mexicanus species. The difference in nomenclature is because it is still unclear which species is which in that general area, because the genus Astyanax is still in need of a revision to clarify species boundaries ( $\mathrm{S}$. Weitzmann, personal communication). Later molecular studies (e.g., Dowling et al. 2002) have confirmed the interpretation that many of the blind, depigmented cave populations of this fish in the Sierra del Abra region in Mexico are the result of independent invasions but they are still closely related from a genetic viewpoint.

However, Proudlove gives the name of Astyanax jordani to the cave populations in order to "follow my own instincts" (p. 51). Proudlove, not only assigns a "new" species status to the cave populations but even claims that all those populations that are the result of different invasions should have different specific names for themselves (p. 53). Given that there are more than 30 cave populations of Astyanax in the same area of Mexico some even having eyes and pigmentation, others "intermediate" (two at least the result of introgressive hybridization) in morphs (Espinasa et al. 2001), that would lead to an incredible confusion of names without a biological basis. Proudlove's reasoning is that there are enough different autapomorphies to name both morphs as different species. He goes on citing a great deal of literature to support his contention. The problem is that none of those authors he cites that have worked with cave Astyanax explicitly or implicitly supports his interpretation of both morphs as different species. In fact, all those authors consider both morphs to be part of the same species.

He criticizes all of us who place both morphs within the same species as having an "uncritical" view of the issue because of interfertility between the two forms. However, he fails to understand all of the progress that has been made in evolutionary biology since the Modern Synthesis in the 1930s. Since genetics became the center of gravity of evolutionary interpretations, the purely "phenetic-only" view of systematics has been aban- doned by virtually all evolutionary systematists and has been replaced by populational thinking where we view nature as a dynamic system that is always in flux and with many continuums. The reductionist-typological ideology fails to appreciate that species are not elements of a periodic table.

Since the development of electrophoretic techniques up to the current more advanced sequence analyses, we have a more complete view of evolutionary processes that reveal the fine grain nature of population structures, phylogenetic relationships, and evolutionary mechanisms. Phenetics alone cannot do that.

If we were to follow the author's typological thinking the different races of dogs and the different human ethnic groups would be different species. After all, current human global population is the result of separate invasions of different areas of the world, and some anthropologists at the turn of the 20th century even classified different human ethnic groups as separate species. We do not need to go to these examples to demonstrate the failings of typological thinking. Typhlichthys subterraneus, a species of the fish family Amblyopsidae of North America, shows an extremely widespread but disjunct distribution with populations even separated by the Mississippi River which strongly suggests they are the result of separate invasions. Some of those populations show some phenotypic variability. Is that enough as to consider dozens of allopatric populations to be each a different species without the appropriate genetic studies?

But there are even larger questions posed by this typological thinking. For example: how to explain recent adaptive radiations, the existence of sibling species and cases of rapid phenotypic evolution with little genetic change? If according to Proudlove blind cave populations of Astyanax that are found in the same area of Mexico should be considered different species by virtue of being the result of different invasions, where are the "autapomorphies" that separate them as different species since they are phenotypically almost identical? How can he explain the cases of introgressive hybridization that have occurred between troglomorphic and non-troglomorphic populations of Astyanax and other species of cave fishes 
(e.g., Romero et al. 2002) in natural conditions if not because they were so closely related from a genetic view point? How about the phenotypic variability shown by these fishes that are result of phenotypic plasticity (Romero and Green 2005)?

This typological thinking is one of the two ghosts that have haunted biospeleological research in general and cave fish research in particular for decades.

The first ghost has been mystical interpretations of evolution, particularly the notion of evolution having a direction; thus, the idea that blind cave fishes are an example of "regressive evolution" although those who use that term can never answer the question of "regressive to where?" Certainly the immediate ancestors of those species of blind cave fishes are not blind, nor were the ancestor of fishes or the ancestors of the chordates themselves for that matter. The authors who hold directional views of evolution do not seem to understand that during evolution even of taxa that are complex from a structural viewpoint, many phenotypic characteristics are lost. For example, not because humans have lost a number of phenotypic characters such as lot of their hair, a tail or their ability to synthesize Vitamin C (among other characters) from their ancestors it means that they are the product of "regressive evolution." This orthogenetic view of evolution has its roots in neo-Lamarckism and was tremendously influenced by French speleologists such as of Armand Viré and René Gabriel Jeannel by mixing early American neo-Lamarckism with French Catholic mysticism. Since French and French-influenced researchers had such a prominence in the establishment of biospeleology as a science, there has been this philosophical confusion in understanding the evolution of cave organisms (Romero 2006).

The utilization of the typological approach to species as "easy" and practical as it looks on the surface, is not really biological, because it leads us to ignore the causes of changes and the underlined genetic mechanisms behind those differences.

But the reason of typology being central to some authors interested in cave life, like the case of Proudlove, has very clear historical roots. Typology originated with Plato's and his student Aristotle's essentialism and had its culmination with Linnaeus' system of classification. Typological thinking has been steadily abandoned since the Modern Synthesis, particularly with the realization that populations contain genetic variation that arises by random mutation and recombination and that under the influence of natural selection, random genetic drift and gene flow results in changes in gene frequency. The final outcome is generally (but not always as in the case of sibling species) phenotypic modifications whose magnitude will vary depending upon both genetic and environmental conditions, leading toward phylogenetic diversification.

The typological thinking expressed in Proudlove's book flourished in the 18th and 19th centuries as naturalists such as Linnaeus wanted to classify what they viewed as God's creations of fixed entities by cataloguing organisms on structurally differentiable characters (Levit and Meister 2006). This ideology was non-phylogenetic in the sense that was non-evolutionary. Once the phenomenon of evolution became widely accepted, typology was then embraced by neo-Lamarckians who believed in directed and/or directional evolution. That evolutionary school was called orthogenesis.

The idea of defining species not as types or "ideal" forms but as a group of populations that share a number of genetic properties is even preDarwinian, going back to at least Leopold von Buch (1774-1853), who first proposed reproductive isolation as a key distinguishing characteristic among species.

Although the Biological Species Concept (BSC) has been criticized for not being universal and lacking diagnosibility for all cases, it is still far more logical than the Evolutionary Species Concept (ESC) and the Phylogenetic Species Concept (PSC), both of which are arbitrary, artificial and non-biological, serving only diagnosibility, which make them germane to the typological concepts of the nineteenth century. It has been convincingly argued that diagnosibility is not a sufficient criterion for a species definition and that the PSC describes species taxa rather than defining a species concept (Glaubrecht 2004). Further, such concepts are closely related from a philosophical view with an orthogenetic view of evolution (Szalay and Bock 1991). No wonder. 
Despite these philosophical and technical shortcomings, Prodlove's book is a valiant and useful compilation of published information. I intend to use it for my own work. However, we should not forget what Louis Agassiz also said more than a century and a half ago: "Study nature, not books".

\section{References}

Alvarez J (1946) Revisión del género Anoptichthys con descripción de una especie nueva (Pisc., Characidae). An Esc Nac Cienc Biol Mex 4:263-282

Alvarez J (1947) Descripción de Anoptichthys hubbsi caracínido ciego de la cueva de los Sabinos, S.L.P. Rev Soc Mex Hist Nat 8:215-219

Avise JC, Selander RK (1972) Evolutionary genetics of cave-dwelling fishes of the genus Astyanax. Evolution 26:1-19

Dowling TE, Martasian DP, Jeffery WR (2002) Evidence for multiple genetic lineages with similar eyeless phenotypes in the blind cavefish Astyanax mexicanus. Mol Biol Evol 19:446-455

Espinasa L, Rivas-Manzano P, Espinosa Pérez H (2001) A new blind cave fish population of genus Astyanax: geography, morphology and behavior. Environ Biol Fishes 63:339-344

Glaubrecht M (2004) Leopold von Buch's legacy: Treating species as dynamic natural entities, or why geography matters. Am Malacol Bull 19:111-134
Hubbs CL, Innes WT (1936) The first known blind fish of the family Characidae:a new genus from Mexico. Occas Pap Mus Zool Univ Mich (342):1-7

Levit GS, Meister K (2006) The history of essentialism vs Ernst Mayr's "Essentialism Story": A case study of German idealistic morphology. Theory Biosci 124:281-307

Mayr E (1982) The growth of biological thought. Diversity, evolution, and inheritance. The Belknap Press of Harvard University Press, Cambridge, 975pp

Romero A (2001) Scientists prefer them blind: The history of hypogean fish research. Environ Biol Fishes 62:4371

Romero A (2006) The big issue between science and religion: purpose vs. uncertainty. Forum on Public Policy 2(4):(in press)

Romero A, Green SM (2005) The end of regressive evolution: examining and interpreting the evidence from cave fishes. J Fish Biol 67:3-32

Romero A, Paulson KM (2001) It is a wonderful hypogean life: A guide to the troglomorphic fishes of the world. Environ Biol Fishes 63:13-41

Romero A., Singh A, McKie A, Manna M, Baker R, Paulson KM, Creswell JE (2002) Replacement of the Troglomorphic population of Rhamdia quelen (Pisces: Pimelodidae) by an Epigean population of the same species in the Cumaca Cave, Trinidad, West Indies. Copeia 2002(4):938-942

Szalay FS, Bock WJ (1991) Evolutionary-theory and systematics - relationships between process and patterns. Zeits Zool Syst Evol 29:1-39

Wilkens H (1971) Genetic interpretation of regressive evolutionary processes: Studies on hybrid eyes of two Astyanax cave populations (Characidae, Pisces). Evolution 25:530-544 